\title{
Role of Bedrock Ground Water in the Initiation of Debris Flows and Sustained Post-Flow Stream Discharge
}

\author{
CHRISTOPHER C. MATHEWSON \\ JEFFREY R. KEATON ${ }^{1}$ \\ PAUL M. SANTI ${ }^{2}$ \\ Center for Engineering Geosciences, Department of Geology, \\ Texas A\&M University, College Station, $T X$ 77843-3115
}

\begin{abstract}
Numerous debris-flow events occurred along the Wasatch Front near Salt Lake City, Utah, during the springs of 1983 and 1984. These flows were distinctly different from the previous damaging flows of 1923 and 1930 which were related to cloudburst thunderstorms. The 1983 and 1984 flows were related to the rapid melting of an above average snow pack. These flows originated as localized failures of colluvial sediment on the upper slopes of the Wasatch Front which had developed on a Precambrian metamorphic bedrock. Following the debris-flow event, "normally dry streams" continued to flow well into the autumn. These sustained flows suggest drainage of a ground-water reservoir, "tapped" by the slope failure and scour of the channel. The supply of ground water contained within the colluvium could not sustain the observed stream flow at the canyon mouth. Therefore, we believe that a bedrock reservoir provided the source of water for sustained stream discharges. Field observations and mapping indicate that the metamorphic bedrock has been highly fractured. Erosion control and range management practices following the 1930 debris-flow events combined with a gradual recovery of the Salt Lake area moisture balance effectively recharged this bedrock aquifer. Excess recharge during the rapid spring melt overcharged the bedrock aquifer, increased the pore-water pressure in the colluvium at locations of bedrock springs and seeps, and led to localized slope failures which mobilized the down canyon colluvium into debris flows. Drainage of the bedrock aquifer, at exposed springs and seeps, maintains the sustained stream discharge seen at the canyon mouths.
\end{abstract}

\section{INTRODUCTION}

Debris-flow hazards have long been recognized at the canyon mouths along the Wasatch Front of Utah

\footnotetext{
' Present address: Sergent, Hauskins and Beckwith, $4030 \mathrm{~S}$. 500 West, Suite 90, Salt Lake City, UT 84123.

${ }^{2}$ Present address: Dames and Moore, 221 Main Street, Suite 600, San Francisco, CA 94105-1917.
}

(Figure 1), having been recorded since settlement of the area in 1847 (Paul and Baker, 1923; Crawford and Thackwell, 1931; Woolley, 1946; Butler and Marsell, 1972; and Marsell, 1972). The most recent episode of debris-flow events occurred during the spring snowmelts of 1983 and 1984. Prior to the 1983-84 debris-flow events, cloudburst debris flows caused substantial damage in 1923 and 1930. Al- 


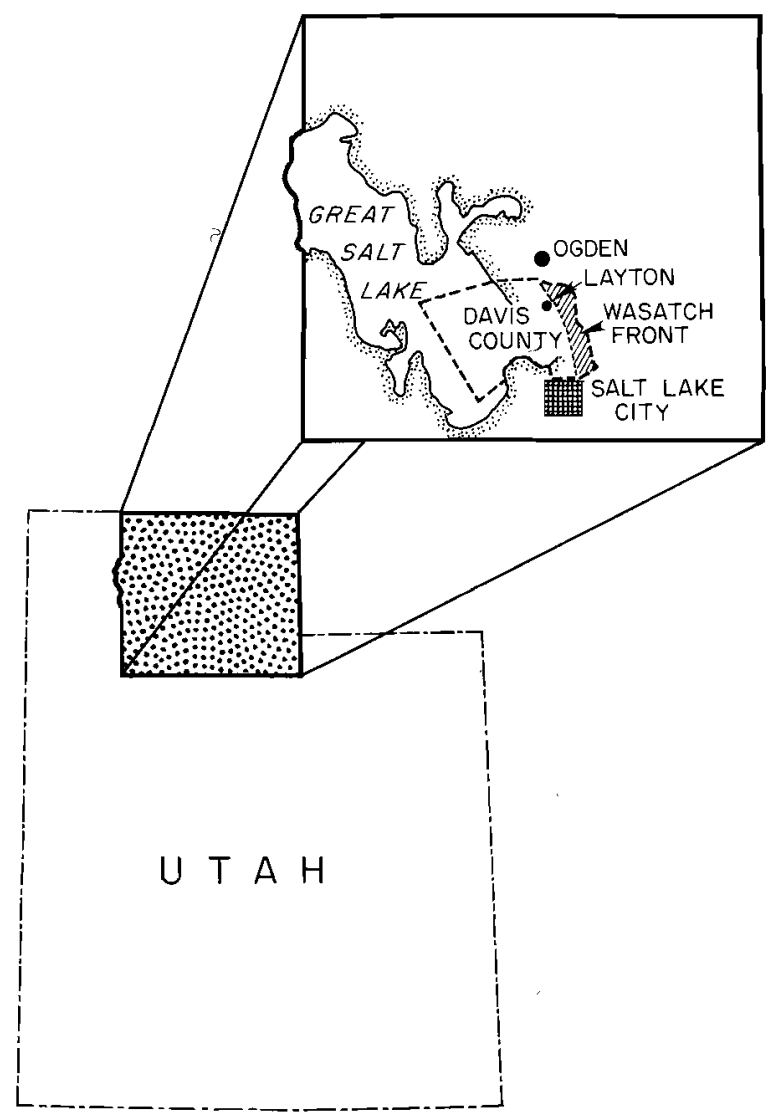

Figure 1. Location of Davis County, Utah. Damaging debris flows have occurred along the Wasatch Front in Davis County throughout the history of settlement in the area. The "East Layton Debris Flow" occurred east of the town of Layton.

though debris floods, which are torrential flows of water carrying somewhat less sediment than debris flows, are nearly annual occurrences in Utah, they are associated with violent summer thunderstorms and not with snowmelt (Costa, 1984; Pierson and Costa, 1987; Woolley, 1946; and Butler and Marsell, 1972). Snowmelt floods did occur in 1922 and 1952; however, accompanying debris flows were not reported (Paul and Baker, 1923; Marsell, 1972).

An extensive range management and debris basin program under the WPA (Work Projects Administration) was implemented following the 1923 and 1930 damaging debris flows. Many of the WPA erosion control structures are still visible today. Butler and Marsell (1972) noted that the 1923 and 1930 debris flows are viewed by many as purely geologic processes, while others blamed human mismanagement of watershed areas as the cause. Keaton (1988) provides an excellent summery of eye witness accounts of the 1923 and 1930 debris-flow events in Davis County, Utah.

\section{CONDITIONS FAVORING DEBRIS FLOWS}

Geologic evidence of past debris-flow events along the Wasatch Front is abundant. Nearly all canyon mouths are occupied by debris fans, which contain boulders with diameters exceeding $1 \mathrm{~m}$. Subsurface data from drillers' logs also indicate large boulders in fine-grained matrices to depths greater than 150 m (Butler and Marsell, 1972). Crawford and Thackwell (1931) reported on prehistoric debris-flow deposits exposed in the fan of Ricks Creek. Keaton (1988) mapped sediments from five prehistoric, postLake Bonneville debris-flow events and five historic debris-flow events on the Ricks Creek fan.

The debris flows of 1983 and 1984 were totally unlike the cloudburst debris flows previously described in Utah by Paul and Baker (1923), Crawford and Thackwell (1931), Cannon (1931), Woolley (1946), Butler and Marsell (1972), and Marsell (1972). The recent debris flows, according to Anderson and others (1984), resulted from a rapid melt of the above-average snow pack, which also contributed to flooding. Marsell (1972) listed seven conditions which contributed to snowmelt floods in 1952; four of these are pertinent to snowmelt debris flows:

1) a thick winter snow pack,

2) saturated soil mantle at the start of winter due to late-autumn rains,

3) abnormally low temperatures during early spring, which retained the deep snow cover, and

4) sustained high temperatures once melting started.

These conditions were repeated during the 1983 and 1984 seasons (Wieczorek et al., 1989).

Costa (1984) noted that small, steep drainage basins have a significant potential to transport eroded soil and rock debris because smaller basins usually exist at high elevations where snow packs accumulate and can melt rapidly, and because they have steep slopes resulting in greater instability of surficial materials. Intense snowmelt saturates permeable surficial deposits, increasing pore-water pressure and the likelihood of slope failures (Costa, 1984). Costa also observed that most debris flows begin as slope failures originating at the heads of swales (small first-order drainages). Most of these initial slope failures consist of slabs or blocks of surficial soils.

Wilson and Dietrich (1987) carried out detailed field investigations and ground-water monitoring of a $16,000 \mathrm{~m}^{2}$ grassland basin in Mt. Tamalpais State Park in Marin County, California. The colluvium in the basin is underlain by a sedimentary bedrock. 


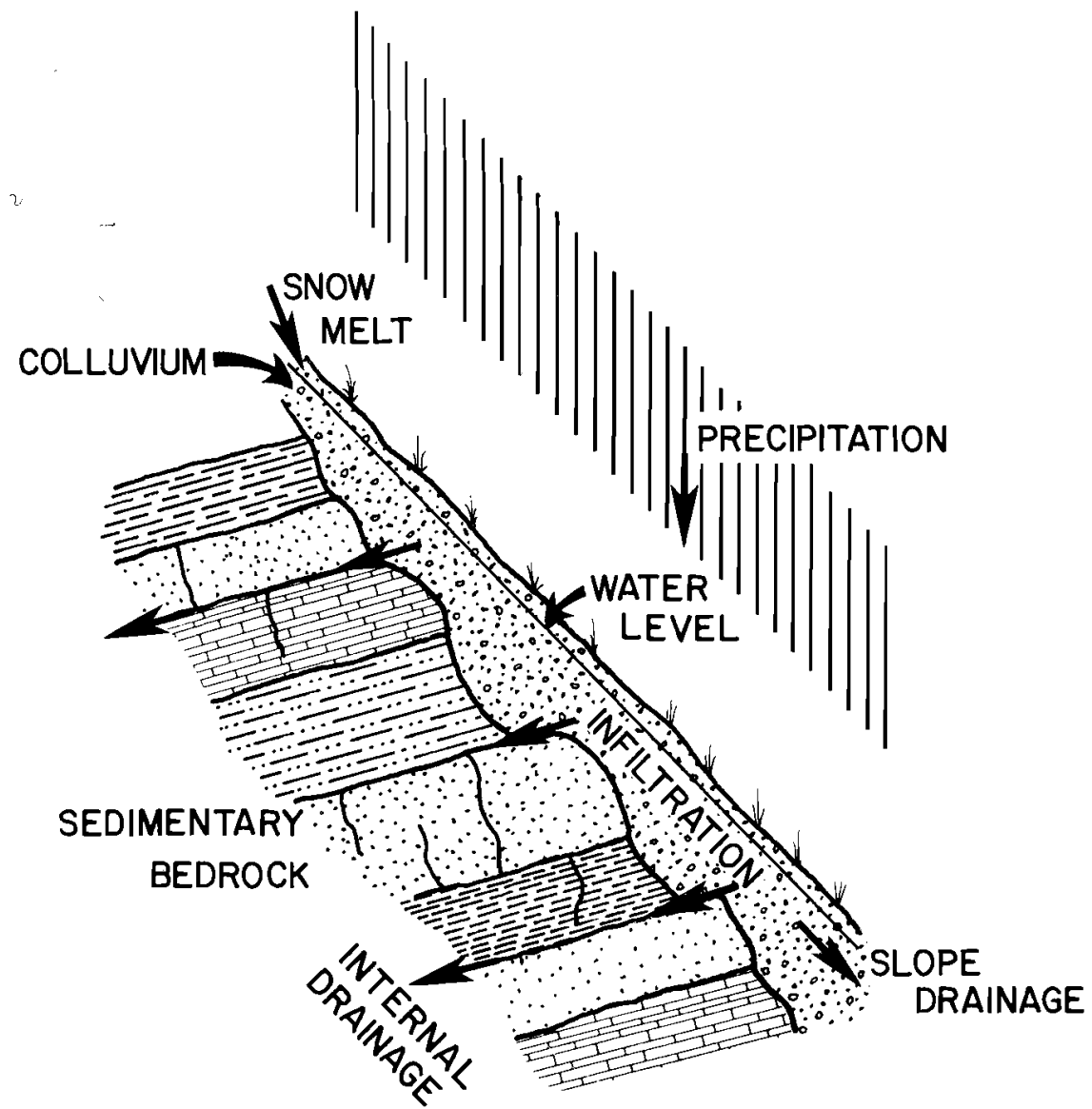

Figure 2. Schematic cross section through the colluvium on a sedimentary bedrock. Campbell (1975) suggests that debris flows are initiated when the rate of precipitation exceeds the rate of colluvium drainage into the sedimentary bedrock and excess pore pressures develop within the colluvium.

They reported that a low-permeability block of bedrock forces a topographically driven ground-water system into the overlying colluvium and that a more permeable bedrock block further downslope allows the ground water to drain from the colluvium. Drainage along the hollow at their site prevents the development of excess pore-water pressures and a resulting failure of the slope. They suggest, however, that on steeper slopes upwelling ground water may provide sufficient pore-water pressures to cause slope failures.

Campbell (1975) documented soil slips and debris flows in the Santa Monica Mountains of Southern California that occurred in response to exceptionally heavy rainstorms from 18 to 26 January 1969. Campbell proposed a model for the initiating mechanism of the soil slips. With sufficient quantities of water, these soil slips would mobilize into debris flows. The model (Figure 2) was developed for geologic conditions consisting of:
1) colluvial soils,

2) sedimentary bedrock,

3) shallow-rooted vegetation, and

4) a deep, permanent water table.

Pore-water pressure in the soil increases when the rate of deep percolation is slower than the rate of infiltration from precipitation or melting snow. Campbell (1975) found that a threshold seasonal rainfall amount must first be met, then certain rainfall intensities will cause surface infiltration to exceed deep percolation, leading to slope failure. Campbell's model has been tested widely and appears to explain most of the landslide/debris-flow features, including many of those observed in Utah (Anderson et al., 1984).

\section{DEBRIS-FLOW HYDRAULICS}

One significant characteristic of certain Utah debris flows has been observed which cannot be ex- 


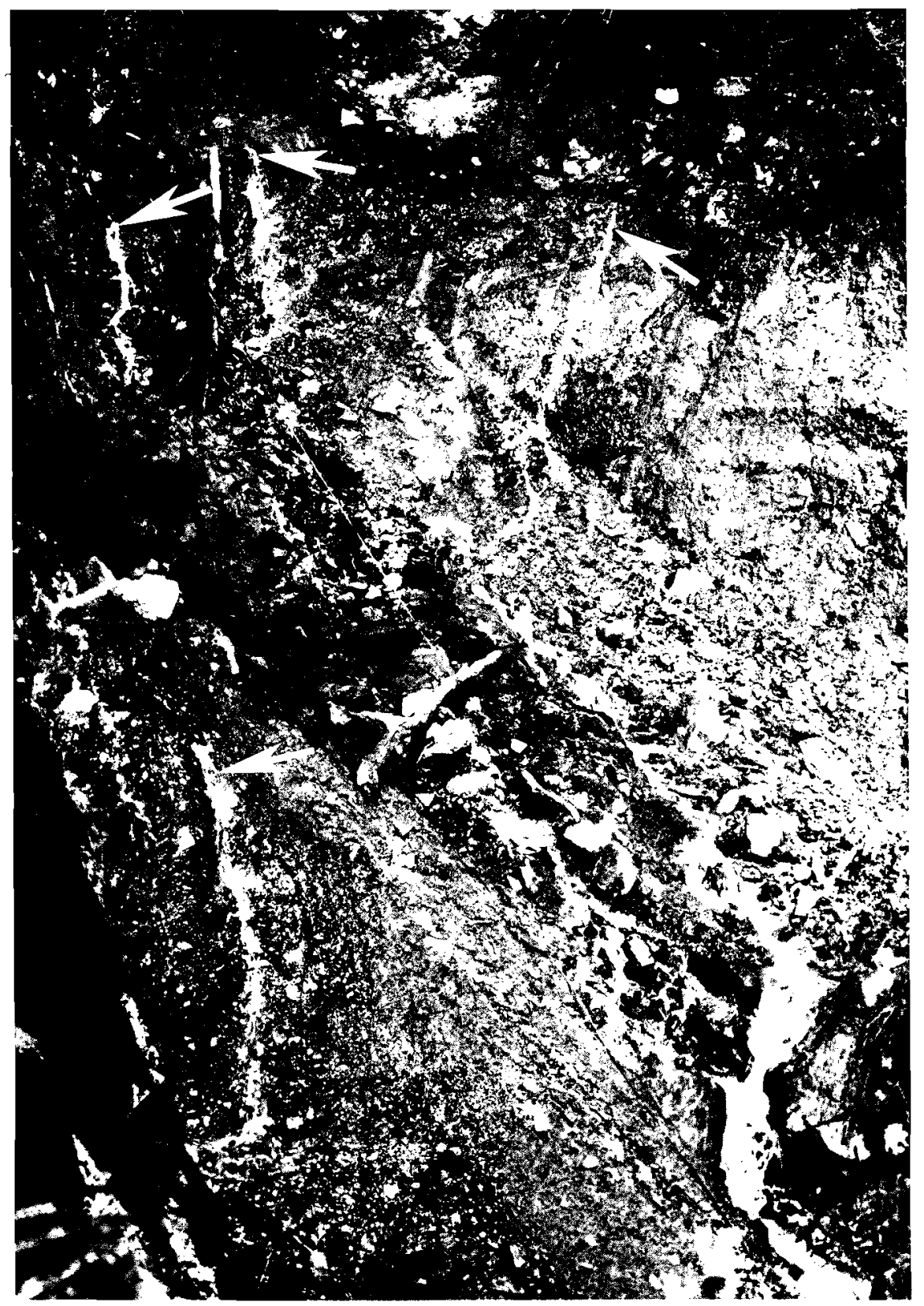

Figure 3. Ground-water discharge spurting under pressure great enough to resemble flow from a hose (arrow). This site, in Rudd Canyon, Utah, is situated on a metamorphic bedrock unit. Photo by M. Kim McCarter.

plained by Campbell's model. This characteristic is sustained, post-debris-flow stream discharge at canyon mouths. The debris-flow source areas, from which sustained ground-water flows have been observed, appear to be restricted to terrain underlain by metamorphic rocks (gneiss and schist) of the Precambrian Farmington Canyon Complex (Wieczorek et al., 1983).

Discussions with Bruce N. Kaliser, then Chief of the Hazards Section, Utah Geological and Mineral
Survey, and M. Kim McCarter, Professor, Department of Mining Engineering, University of Utah in 1984, revealed that a number of the 1983 and 1984 debris flows occurred in typically "dry" valleys and that, following the failures, significant flows of water could be seen issuing from the source scars (Figure 3). Some ground-water discharges from debris-flow scar springs were under such pressure that the discharge was described "as if it were coming from a hose." These discussions revealed that, following 


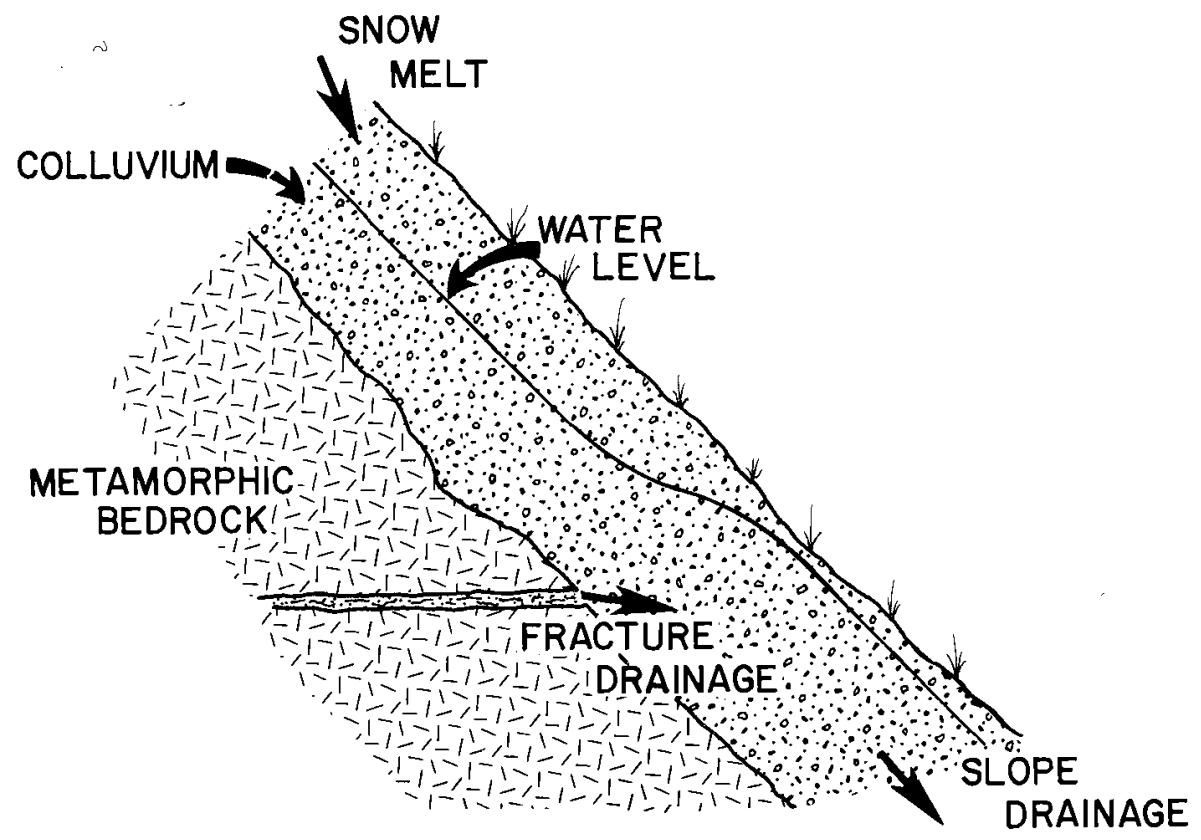

Figure 4. Schematic cross section through the colluvium on a metamorphic bedrock. Elevated hydrostatic pressure within the fracture, due to excess recharge to the bedrock aquifer, increases fracture drainage and leads to elevated pore-water pressures and saturation of the colluvium. Given a critical slope angle the colluvium fails and initiates the debris flow. Drainage of the fractured, bedrock aquifer through the exposed fracture forms a spring and maintains canyon-mouth stream discharge.

debris flows, renewed stream flow in previously dry streams was not uncommon for that part of the Wasatch Front underlain by metamorphic rocks.

Bedrock was commonly exposed in the debris source scars and along the scoured debris-flow channel. Ground-water flow from seeps and springs in the exposed bedrock supplied the water to maintain stream discharge in 1989. In many cases these streams were observed to flow for extended periods of time following the debris-flow event, often into the autumn, long after the snow pack had melted. Stream discharges were also significantly greater than those prior to the debris-flow events.

It is hypothesized that these debris flows were initiated by a buildup of pore-water pressures within the colluvium. The source of this water is believed to be from ground-water drainage from fractures within the metamorphic bedrock (Figure 4). This mechanism is similar to that proposed by Wilson and Dietrich (1987) where the hydrogeologic system in the bedrock is heterogeneous. It is further proposed that the sustained stream discharge represents the drainage of a bedrock aquifer system.

\section{THE EAST LAYTON DEBRIS FLOW}

During a field study of debris-flow sites north of Salt Lake City, the authors had an opportunity to discuss the history of events of a debris flow with the owner of a damaged house at the mouth of Lightning Canyon, a small $\left(0.55 \mathrm{~km}^{2}\right)$ canyon east of Layton, Utah (Figure 1). The homeowner, who had occupied the house for the previous 28 years, reported that the debris flow occurred at about 6:20 AM on 14 May 1984, as a series of three waves, each carrying progressively finer-grained materials and becoming wetter, followed by significant flows of clear water. He described the sequence of events of the "East Layton Debris Flow" as:

1) an initial wave which came down the valley as a massive, rolling wall of debris containing boulders in a mud matrix;

2) a second wave containing gravels mixed with clay and silt that was wetter than the first and progressed farther down the fan;

3) a third flow dominantly composed of muddy water that extended about $100 \mathrm{~m}$ farther down the fan; followed by

4) muddy water that cleared up and continued to flow.

The homeowner reported that the stream (Figure 5) typically flowed only after rainstorms and then rapidly "dried up"; however, following the 1984 debris-flow event, stream discharge continued well into the month of October. The homeowner also stated that the source area for the initial slope failure 


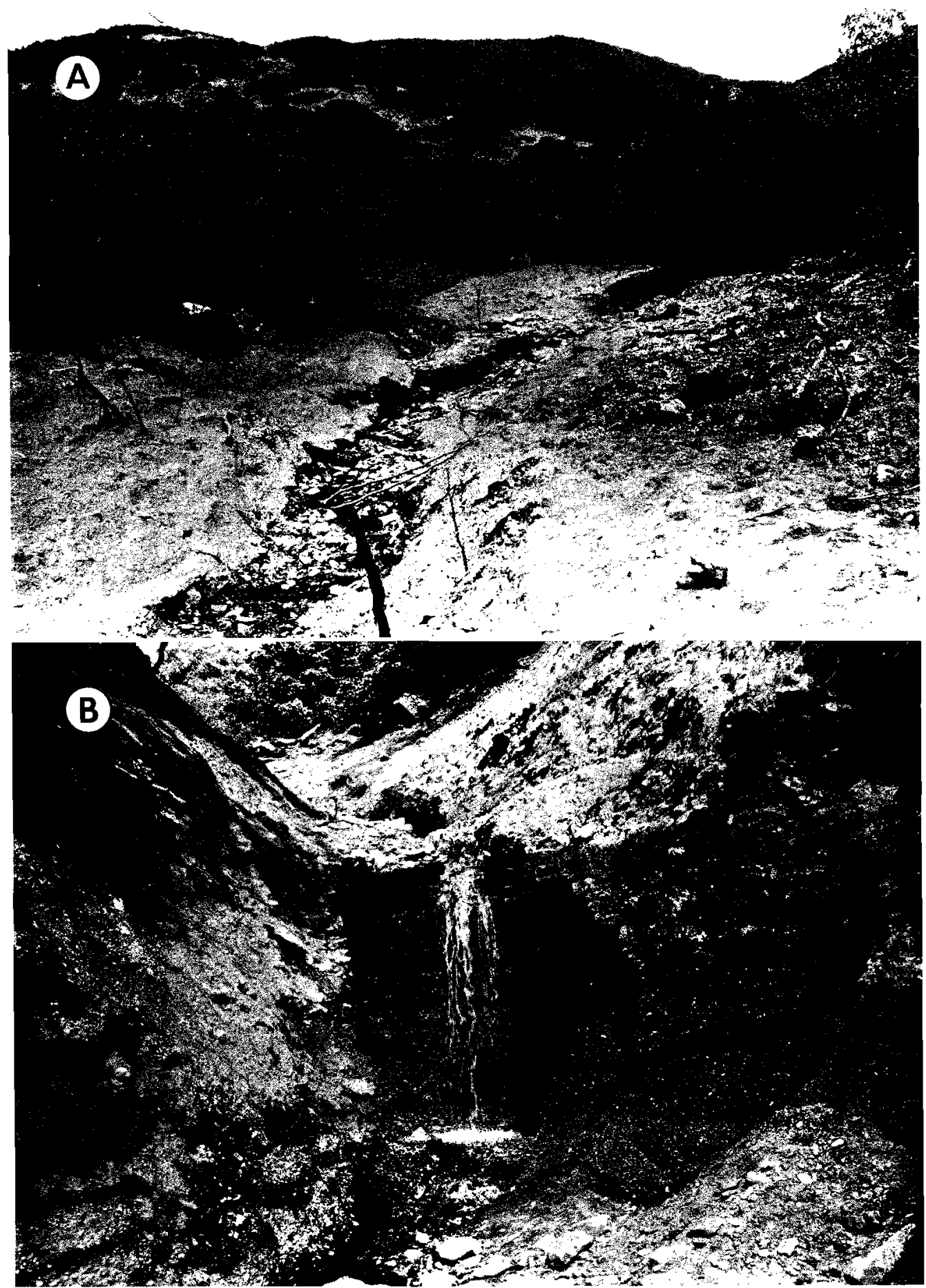

Figure 5. Stream flowing (A) through the debris fan and (B) in the channel about $200 \mathrm{~m}$ upstream in Lightning Canyon near East Layton, Utah, on 13 June 1984. This stream typically flowed only after a rainstorm event and rapidly dried up until the 14 May 1984 debris-flow event.

was nearly always wet and marshy and locally known as "Muddy Spring."

Olson (1985) reported that the lower limit of the snow pack on the Wasatch Range in the vicinity of
East Layton was above 2,100 $\mathrm{m}$ in mid-May 1984. The source scar of the East Layton Debris Flow was about $200 \mathrm{~m}$ below the snow line at the time of failure. Temperatures during this period were above 


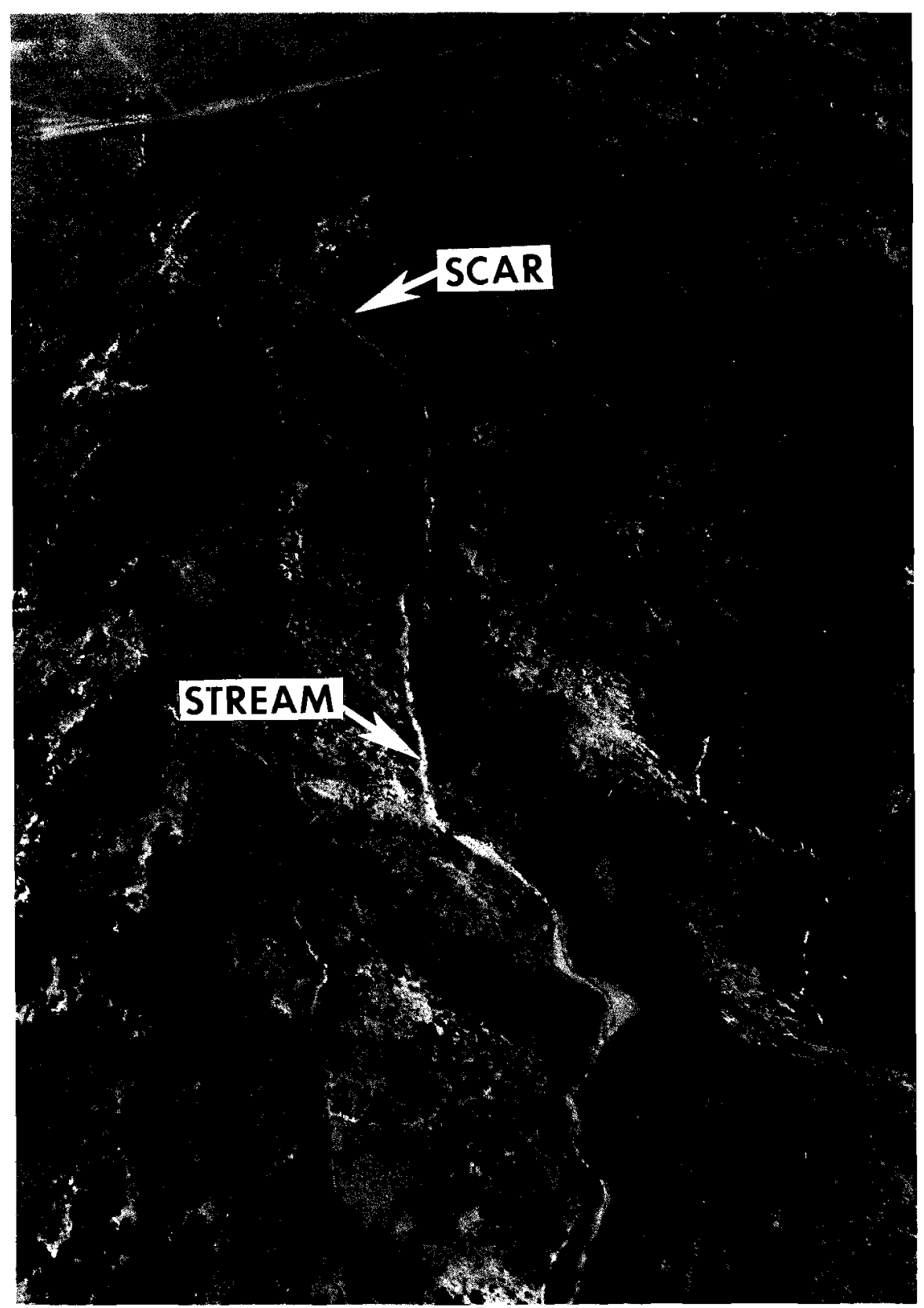

Figure 6. Aerial photograph of the East Layton Debris-Flow scar and channel. Note the small size of the debris-flow scar and the narrow cleared area where the flow moved down the valley.

freezing; a low of $19^{\circ} \mathrm{C}$ was recorded for the night of 13 May in Ogden, Utah and the predicted high for 14 May was $32^{\circ} \mathrm{C}$ (Baker, 1984). Rapid melting of the snow pack under these warm conditions would provide the necessary water to initiate the slope failure.

A low-altitude aerial reconnaissance (Figure 6) of the debris flow revealed that the source was very limited in areal extent and located at the outer edge of a mountain spur. A significant amount of water was seen flowing from springs located from near the base of the source scar to well down the channel.

Field surveys determined that the volume of material removed from the debris-flow scar was only $240 \mathrm{~m}^{3}$, while the total amount of debris mobilized in the East Layton Debris Flow was more than 12,500 $\mathrm{m}^{3}$ (Santi and Mathewson, 1988). Santi $(1988,1989)$ concluded that the initial failure was a rotational 
slump on a $30^{\circ}$ slope caused by elevated pore-water pressures within the colluvium. It is suggested that the water was derived from a bedrock aquifer because the site was known to be wet and marshy prior to the debris-flow event.

Santi $(1988,1989)$ also evaluated the kinematics of debris-flow transport and mobilization of colluvium down the canyon. He concluded that mobilization of the colluvium was related to loading, by debris from above, combined with saturated and undrained conditions along the canyon. Loading caused an abrupt increase in pore-water pressure that resulted in the loss of stability of the colluvium and incorporation into the debris-flow mass.

For sustained canyon-mouth stream discharge to occur following the East Layton Debris Flow, a ground-water reservoir must exist in the drainage basin. In the case of this debris flow, sustained stream discharge continued for approximately 5 months after the initial debris-flow event, from mid-May to mid-October 1984. Stream discharge during 1985 and 1986 continued from the start of snow-pack melt to late-July/early-August. By 1987 the stream discharge ceased in the spring, indicating that the reservoir had drained or was not recharged during the previous winter.

Based on the authors' observations and comments from local residents, the long-term average stream discharge following the debris-flow event was estimated to be $0.03 \mathrm{~m}^{3} / \mathrm{sec}$. This yields over 388,000 $\mathrm{m}^{3}$ of water discharged at the canyon mouth during 1984. The approximate area of the drainage basin for the stream at East Layton is less than 600,000 $\mathrm{m}^{2}$. An average thickness of the colluvium of $2 \mathrm{~m}$ yields a total volume of the colluvium in the basin of 1.2 million $\mathrm{m}^{3}$. Assuming a porosity of 30 percent for the silty gravel material, a total volume of 360,000 $\mathrm{m}^{3}$ of water would have been stored in the colluvium. Assuming that 30 percent of this stored water can be supplied to the stream system and 70 percent is held in the clayey-silt matrix, the total volume of water released is only $108,000 \mathrm{~m}^{3}$. These estimates indicate that the entire volume of stored water within the colluvium is approximately equal to the total flow at the canyon mouth for 1984. Stream discharges the following years, which had more normal moisture conditions, continued to exceed flows that were reported by local residents prior to the 1984 debris-flow event.

The discharge from Lightning Canyon suggests that the ground water stored within the colluvium was insufficient to supply the entire sustained flow.
Therefore, an additional ground-water reservoir must also exist. It is suggested that this reservoir lies within the fracture system of the Farmington Canyon Complex.

Ala (1989) shows, from field mapping, a dense network of fractures within the metamorphic bedrock of the Wasatch Front. Regional lineaments, seen in aerial photographs, are oriented N-S and NW-SE, and are probably associated with the Wasatch fault. These lineaments are cut by a complex series of low angle fractures, which when combined with the lineaments produces an isotropic fracturedbedrock aquifer system.

Field observations of the East Layton Debris Flow suggest that debris flows followed by sustained stream discharges in the Wasatch Front can be characterized as follows:

1) The debris flows are typically developed on terrain underlain by metamorphic rock units.

2) The flows are often initiated within or near swales, springs or drainage features on the upper slope and can occur very close to a ridge.

3) The debris-flow source areas are generally small and appear to be sites where excess pore water pressures induced failure of the colluvium.

4) Springs located within the sites are exposed in the failure scar and along the scoured channel.

5) The springs exposed in the debris-flow scars supply sufficient water to sustain flowing streams that did not exist before the debris flows occurred.

6) Sustained stream flows at the canyon mouths are commonly observed for years after the debrisflow event.

7) Removal of the confining colluvial cover through debris-flow processes exposes bedrock fractures and allows the bedrock reservoir to drain.

\section{BEDROCK AQUIFER SYSTEM}

Field and historical evidence indicates that springs exist in many of the canyons and on the upper flanks of the mountain. Farmington City developed a number of springs near the head of Rudd Creek in Rudd Canyon for a municipal water supply. These springs were abandoned when they could no longer supply the needs of Farmington and when an aqueduct was constructed. Olson (1985) reported that a number of "blind" springs or wet areas are known throughout the region. He also stated that the bedrock ground-water system is generally unknown.

Recent field studies of the mountain springs in- 


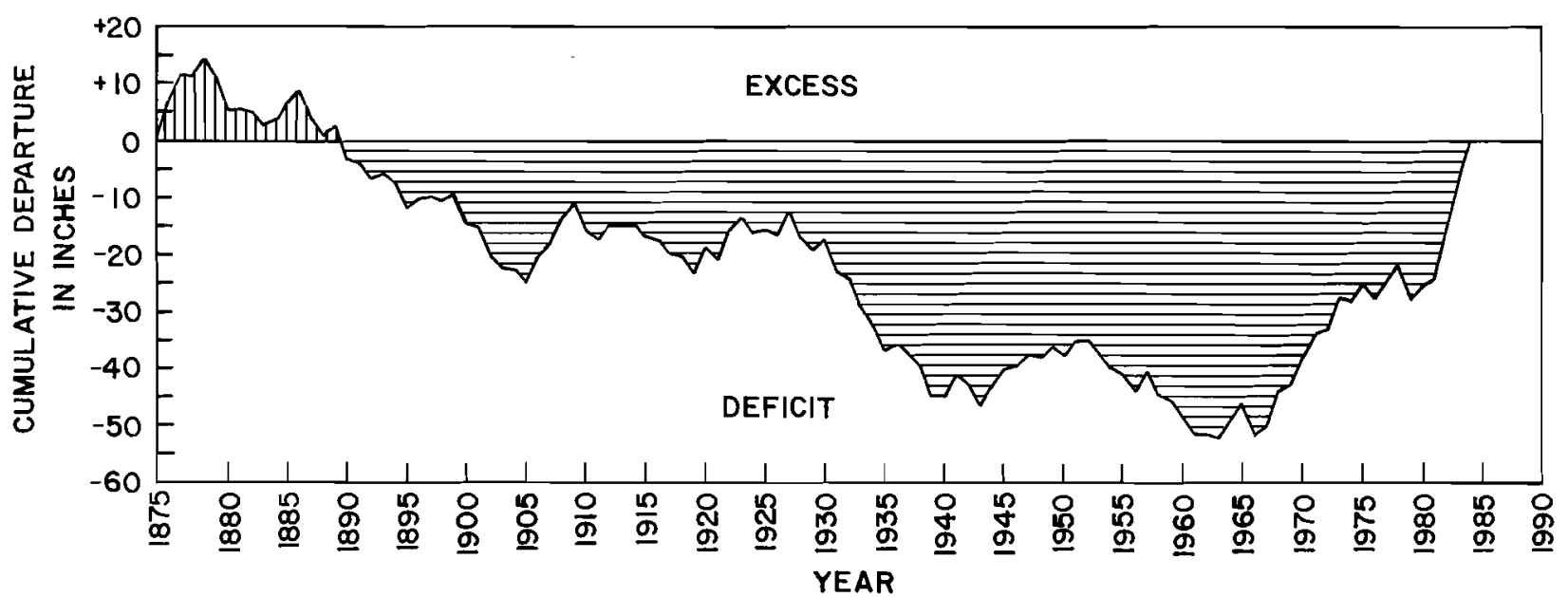

Figure 7. Cumulative departure from mean precipitation, Salt Lake City, measured at the Weather Service Office, Salt Lake City Airport. Note that a return toward historically normal conditions that started in the mid-1960's after a nearly steady decline from the 1890 's.

dicate that pegmatite dikes in the Farmington Canyon Complex tend to control the locations of some springs. Ala (1989) suggests that these dikes and other bedrock features form permeability heterogenities within the bedrock that establish the sites of springs.

Further evidence supporting the presence of a bedrock ground-water system is seen in the vegetative response to the 1983 and 1984 debris-flow events. Numerous aspen groves had developed on the WPA contour trenched slopes, and "wet land" vegetation had grown around mountain springs by 1980. It is suggested that drainage from a fractured bedrock aquifer maintained a shallow ground-water table in the colluvium, and that inefficient groundwater drainage through fractures in the bedrock maintained the water levels within the bedrock aquifer. By the late-1980's the high-water demand vegetative cover was seen to have died back. These vegetative changes indicate that a shallow groundwater supply within the colluvium decreased as the mountain block drained following the 1983 and 1984 debris flows (Coleman, 1989).

The climatic conditions necessary to establish a charged bedrock aquifer require a gradual buildup of water. The temporal association of debris flows with rapidly melting snow indicates that the rapid supply of meltwater contributed to elevating already high pore-water pressures within the colluvium to values above the threshold required for failure.

Precipitation within the Wasatch Front region over the period 1982-84 supplied significant quantities of water to the mountain watersheds. Cumulative departure from mean precipitation for the Salt Lake City area (Figure 7) shows that a positive departure persisted prior to 1890 , while a negative departure existed until 1984. The water years 1981-82, 198283, and 1983-84 were the first, fifth, and second wettest periods in the 137-year history of Salt Lake City.

The moisture budget in the Salt Lake City area began to recover in the early 1960's. It is suggested that this moisture recovery, combined with the WPA erosion control measure and improved range management, allowed the bedrock ground-water system to recharge. It is further suggested that the excess moisture, supplied during 1981-84, led to overcharging of the bedrock aquifer, elevated pore-water pressures within the colluvium and slope failures which mobilized into debris flows.

\section{DEBRIS-FLOW MECHANISMS}

It is suggested that debris flows along the Wasatch Front were initiated by two distinctly different hydrogeologic mechanisms. In one case, the rate of surface infiltration exceeds the rate of internal drainage of the colluvium into an internally drained bedrock, allowing a buildup of pore pressures and slope failure, as proposed by Campbell (1975). Because the mechanism to elevate pore pressures relies on shallow infiltration of water from precipitation or snowmelt exceeding the rate of internal drainage into the bedrock, the ground-water reservoir is confined to the colluvium or deep within the bedrock. Following failure, excess ground water contained 
within the colluvium quickly drains into the stream or underlying bedrock and stream discharge ceases.

In the other case, the bedrock is a fractured crystalline rock, as on the metamorphic units of the Wasatch Front, or any impermeable bedrock that is not internally drained. Infiltration of rainfall and snowmelt recharges a confined, fractured bedrock ground-water system which is discharging into the overlying colluvium, thereby preventing internal drainage. Sustained recharge, as was the case in 1983 and 1984 , leads to increased pore pressures within the colluvium at buried discharge points within the bedrock. Given sufficient pressures and slope angles, the colluvium eventually fails and exposes fractures in the debris-flow scar and channel. These exposed fractures become springs that supply the observed stream discharge seen after the debris-flow event.

A hypothesized mechanism for the initiation and sequence of events of debris flows, which produce sustained canyon-mouth stream discharge from a bedrock ground-water reservoir, is outlined below:

1) Tectonic processes produce a complex series of interconnected fractures in an otherwise massive impermeable bedrock.

2) Colluvial soils form on the bedrock units and cover the fractures.

3) Precipitation recharges the fractures in the bedrock, and a shallow ground-water system is established and maintained in the colluvium through ground-water seepage from the bedrock.

4) Excess recharge of a fully charged bedrock aquifer allows the pore-water pressures to build until the colluvium fails, as a "burst" or "blow out," and mobilizes into a debris flow. This failure mechanism is in agreement with that proposed by Eisenlohr (1952), Hack and Goodlett (1960) and suggested by Wilson and Dietrich (1987).

5) Rapid depressurization and drainage of the fractures may induce erosion of the fracture filling contributing to an increase in the permeability of the fractures in the bedrock.

6) Fracture-dominated, ground-water systems continue to drain and supply water for sustained stream discharge at the canyon mouth until the reservoir has drained.

\section{ACKNOWLEDGEMENTS}

The authors are indebted to Mr. Jeff Warburton of Layton, Utah for providing access to his property to investigate the "East Layton Debris Flow" and for his personal observations of the debris-flow event.
Loran Anderson, Gerald Wieczorek, Russell Campbell, Robert Fleming, and Elliott Lips provided valuable comments on this manuscript. The authors also appreciate the comments by the reviewers for the Bulletin of the Association of Engineering $\mathrm{Ge}$ ologists.

A portion of the work was supported through U.S. Geological Survey Landslide Hazard Reduction Program Agreement Number 14-08-0001-A0507, Utah Geologic and Mineral Survey Contract Number 88-0886 with Utah State University; by the Utah Geologic and Mineral Survey; and by the Center for Engineering Geosciences at Texas A\&M University.

\section{REFERENCES}

Ala, Souren, 1989, Abstract, The influence of bedrock on debris flows along the Wasatch Front, Utah: Abstracts and Program, 1989 Annual Meeting of the Association of Engineering Geologists, Vail, CO, p. 48.

ANDERson, L. R.; Keaton, J. R.; SAarinen, T. F.; AND Wells, W. G. II, 1984, The Utah Landslides, Debris Flows and Floods of May and June 1983: National Academy Press, Washington, DC, $96 \mathrm{p}$.

BAKER, D., 1984, Homes evacuated in Davis Slide, Ogden Standard Examiner, 97th year, No. 135, May 14, pp. 1A-2A.

Butler, Elmer and Marsell, R. E., 1972, Cloudburst Floods in Utah, 1939-69, Utah Department of Natural Resources, Division of Water Resources, Cooperative Investigations Report No. 11: Utah Department of Natural Resources, Salt Lake City, UT, 103 p.

Campbell, R. H., 1975, Soil Slips, Debris Flows, and Rainstorms in the Santa Monica Mountains and Vicinity, Southern California, U.S. Geological Survey Professional Paper 851: U.S. Geological Survey, Denver, CO, 51 p.

CANnon, S. Q. (EDITOR), 1931, Torrential Floods in Northern Utah, 1930, Utah Agricultural Experiment Station, Circular 92: Utah State University, Logan, UT, 51 p.

Coleman, W. Kevin, 1989, Abstract, Role of contour trenching in the alteration of hydrogeologic conditions of the Wasatch Front: Abstracts and Program, 1989 Annual Meeting of the Association of Engineering Geologists, Vail, CO, p. 57.

CostA, J. E., 1984, Physical geomorphology of debris flows. In Costa, J. E. and Fleisher, P. J. (editors), Developments and Applications of Geomorphology: Springer-Verlag, New York, pp. 268-317

Crawford, A. C. and Thackwell, F. E., 1931, Some Aspects of the Mud Flows North of Salt Lake City: Utah Academy of Sciences Proceedings, Vol. 8, pp. 97-105.

EISENLOHR, W. S. JR., 1952, Floods of July 18, 1942, Pennsylvania, in Notable Floods of 1942-43, U.S. Geological Survey Water Supply Paper 1134B: U.S. Geological Survey, Denver, CO, pp. 75-78.

HACK, J. T. AND GoODLETT, J. C., 1960, Geomorphology and Forest Ecology of a Mountain Region in the Central Appalachians, U.S. Geological Survey Professional Paper 347: U.S. Geological Survey, Denver, CO, pp. 45-47.

Keaton, Jefrey R., 1988, A Probabilistic Model for Hazards Related to Sedimentation Processes on Alluvial Fans in Davis County, Utah: Unpublished PhD Dissertation, Department 
of Geology, Texas A\&M University, College Station, TX, $441 \mathrm{p}$.

MARsell, R. E., 1972, Cloudburst and snowmelt floods, in Environmental Geology of the Wasatch Front, 1971, Utah Geological Association Publication 1: Utah Geological Association, Salt Lake City, UT, pp. N1-N18.

Olson, EARL P., 1985, East Layton Debris Flow, Environmental Geology, Level 2 Case Study; U.S. Department of Agriculture, R-4 Intermountain Region, Report G, R-4, 85-2: U.S. Department of Agriculture, U.S. Forest Service, Washington, DC. 25 p.

PAUL, J. H. AND BAKER, F. S., 1923, The Floods of 1923 in Northern Utah, University of Utah Bulletin, Vol. 15: University of Utah, Salt Lake City, UT, 20 p.

Pierson, T. C. ANd Costa, J. E., 1987, A rheological classification of subaerial sediment-water flows. In Costa, J. E. and Wieczorek, G. F. (editors), Debris Flows/Avalanches: Process, Recognition, and Mitigation, Reviews in Engineering Geology, Volume VII: Geological Society of America, Boulder, CO, pp. 1-49.

Santi, Paul M., 1988, The Kinematics of Debris Flow Transport Down a Canyon: Unpublished Master of Science Thesis, Department of Geology, Texas A\&M University, College Station, TX, $85 \mathrm{p}$.

Santi, Paul M., 1989, The kinematics of debris flow transport down a canyon: Bulletin of the Association of Engineering Geologists, Vol. XXVI, No. 1, pp. 5-9.
Santi, Paul M. and Mathewson, Christopher C., 1988, What happens between the scar and the fan? The behavior of a debris flow in motion. In Fragazy, Richard J. (editor), 24th Annual Symposium on Engineering Geology and Soils Engineering: Coeur d'Alene, ID, pp. 73-88.

Wieczorek, G. F.; Ellen, Stephen; Lips, E. W.; Cannon, S. H.; AND Short, D. N., 1983, Potential for Debris Flow and Debris Flood along the Wasatch Front between Salt Lake City and Willard, Utah, and Measures for their Mitigation, U.S. Geological Survey Open-File Report 83-635: U.S. Geological Survey, Denver, CO, 45 p.

Wieczorek, G. F.; Lips, Elliott W.; And Ellen, Stephen D., 1989, Debris flows and hyperconcentrated floods along the Wasatch Front, Utah, 1983 and 1984: Bulletin of the Association of Engineering Geologists, Vol. XXVI, No. 2, pp. 191-208.

WiLSON, C. L. AND DiETRICH, W. E., 1987, The contribution of bedrock groundwater flow to storm runoff and high pore pressure development in hollows, in Erosion and Sedimentation in the Pacific Rim: International Association of Scientific Hydrology (IAHS) Publication No. 165, pp. 49-59.

Woolley, R. R., 1946, Cloudburst Floods in Utah, 1850-1938, U.S. Geological Survey Water Supply Paper 994: U.S. Geological Survey, Denver, CO, 128 p. 